\title{
Effects Of Orally Fed Diazinon On Some Biochemical Parameters Of Male Albino Rats
}

\author{
Mohammed Salah Ab.Ab.AL-Shinnawy \\ Biological and Geological Sciences Department, Faculty of Education, Ain Shams \\ University, Cairo, Egypt .
}

\begin{abstract}
Background:The current investigation was carried out to study the effect of orally administration of diazinon insecticide on some biochemical blood indices on male albino rats.

Material and methods: The organophosphorus insecticide, diazinon was orally administrated at a dose $(100 \mathrm{mg} / \mathrm{kg}$ body weight=1/3LD50), daily for 10 days (short - term) and 20 days (long -term) to adult male albino rats .

Results: The results revealed the following:

1- Diazinon led to an increase in rat blood serum glucose \& T3 (short and long -term); AST,ALT, and T4 (long-term).

2- Diazinon reduced the serum content of total cholesterol and protein in short-term treated rats.

3- Treatment of rats with diazinon did not alter activity of AST, ALT and T4 level at short -term period .In addition; ALP serum levels were not altered in both short and long-term treated rats .
\end{abstract}

Key Words: Diazinon, Organophosphorus insecticide , Biochemical changes , Serum

\section{Introduction}

The world loses about 6 billion pounds sterling every year of agricultural production due to pests. Farmers have therefore invested heavily in pesticides to reduce this loss. The international use of pesticides has increased food production in parallel with population growth in many parts of the world .Many insect - borne diseases have also been eliminated or controlled by the use of insecticides (Sungur and Güven, 2001).

On the other hand ,the extensive use of insecticides to control agricultural pests has caused great concern because of the possible effects of these compounds on human beings as well as wild and domestic animals (Ezzat et al.,1991 and Alpalan et al. ,2006) .

The organophosphorus insecticides comprise a very large group of compounds . They constitute the most important group of modern pesticides, being of wide application because they possess a high insecticidal activity as well as a high initial action of toxicity on pests (Hassall , 1990 ; Gralewicz \& Socko , 1997).
Diazinon which is the object of this current study is one of the organophosphorus insecticides (Cindy et al., 2007). It has been used at levels exceed the legal limits to control a wide variety of sucking and chewing insects and mites on a very wide range of crops, including deciduous fruit trees, citrus fruit, vines olives ,bananas , pineapples ,etc......Also used as a veterinary ectoparasiticide .It has hazardous side effects on humans and economic farm animals that accidentally exposed to it (Kalender et al .,2005).

\section{Material And Methods}

Forty mature male albino rats (Rattus norvegicus)ranging in weight from 120 $140 \mathrm{gm}$. , were essentially obtained from Schistosoma Biological Supply Program (SBSP) Theodor Bilharz Research Institute. The rats were allocated at random into 4 equal groups 10 rats each.

The first group,were kept as control being observed under the same laboratory conditions. 
The second group,each rat of this group was orally given a dose $(100 \mathrm{mg} / \mathrm{kg}$ body weight) daily of diazinon pesticide for 10 days(short - term).

The third group,rats of this group were served as a control group (long - term treatment).

The fourth group,each rat of this group was orally given $100 \mathrm{mg} / \mathrm{kg}$ body weight daily of diazinon for 20 days (long term treatment).

All of the control and treated animals were individually weekly weighed in order to detect any change that may take place in their body weights.

\section{Biochemical studies:}

At the end of experimental periods ,individual samples were then collected from the different groups after $18 \mathrm{~h}$. fast. Samples of blood drawn and left to clot in a clean dry test tube for each animal, then centrifuged at $3000 \mathrm{rpm}$ for ten minutes. Part of the clear supernatant serum was used immediately for glucose determination. The remain serum was frozen at 20C for the subsequent analysis.

Serum glucose level was measured according to the "enzymatic colorimetric" method described by Trinder(1969). The total serum cholesterol was carried out according to Allain et al. (1974). Serum total protein was estimated according to the method described by Domas(1975). Serum aspartate transaminase (AST) and alanine tansaminase (ALT) activities were carried out according to Berg Meyer and Bernt (1974). Serum alkaline phosphatase(ALP) was determined by the method of Belfield and Golbderg(1971).

Determination of thyroxine (T4) was carried out by using solid phase enzyme immunoassay according to the method of Wood (1980). Measurement of serum tri iodothyronine (T3) concentration was done by using enzyme - immunoassay Kit purchased from (Boehringer Manheim West Germany).

\section{Data analysis}

Biological data resulted in the present study were computed and analysed statistically according to the mathematical principles of handling frequency distributions described by Compbell (1974).

\section{Results}

Results of the effects of repeated doses of diazinon pesticide on body weights of the rats are recorded in table(1). The findings indicated that treated rats showed highly significant decreases $(\mathrm{P}<0.001)$ in their body weights after feeding for 20days , while the body weight was not obviously changed on the other tested period (10days).

The data represented in table (2) display the effect of diazinon pesticide on serum glucose level, total cholesterol and protein content. The glucose levels of all treated groups recorded high significant increase $(\mathrm{P}<0.001)$, while serum content of total cholesterol was highly significant decrease $(\mathrm{P}<0.001)$ in short - term treated group, but it was significantly decrease $(\mathrm{P}<0.05)$ in long - term treated group.

Total proteins were highly significant decreased $(p<0.001)$ in serum of treated rats (at short - term) and decreased $(\mathrm{P}<0.05)$ (at long - term).

The obtained data (recorded in table3), short term administration of diazinon showed insignificant changes in the activities of AST,ALT and ALP in rats. The activity of these transaminases after long - term administration of diazinon , was highly significant increased $(\mathrm{P}<0.001)$ in these animals.

Serum T3 levels was highly significant elevate $(\mathrm{P}<0.001)$ above the control values after 10 and 20days in response to the diazinon treatment (table 4).Data presented in the same table indicated that administration of diazinon into rats led to significantly increase $(\mathrm{P}<0.05)$ in $\mathrm{T} 4$ concentration in long - term treated rats. 
Table (1): Effect of Diazinon insecticide on body weight(gain or loss) ( gm) of rats .

\begin{tabular}{|c|c|c|c|c|}
\hline \multirow{2}{*}{} & \multicolumn{2}{|c|}{ After 10 days } & \multicolumn{2}{c|}{ After 20 days } \\
\cline { 2 - 5 } & Control & Treated & Control & Treated \\
\hline $\begin{array}{c}\text { Mean of body weight (gain or loss } \\
\text { gm .) (Mean } \pm \text { S . D) }\end{array}$ & $\begin{array}{c}6.11 \\
\pm 0.89\end{array}$ & $\begin{array}{c}5.46 \\
\pm 1.09\end{array}$ & $\begin{array}{c}9.48 \\
\pm 0.60\end{array}$ & $\begin{array}{c}8.06 \\
\pm 0.50\end{array}$ \\
\hline \% of change & \multicolumn{2}{|c|}{-10.63} & \multicolumn{2}{c|}{-14.99} \\
\hline P value & \multicolumn{2}{|c|}{$\mathbf{P}>\mathbf{0 . 0 5}$} & $\mathbf{P}<\mathbf{0 . 0 0 1} * * *$ \\
\hline
\end{tabular}

*Insignificant

*** Highly Significant

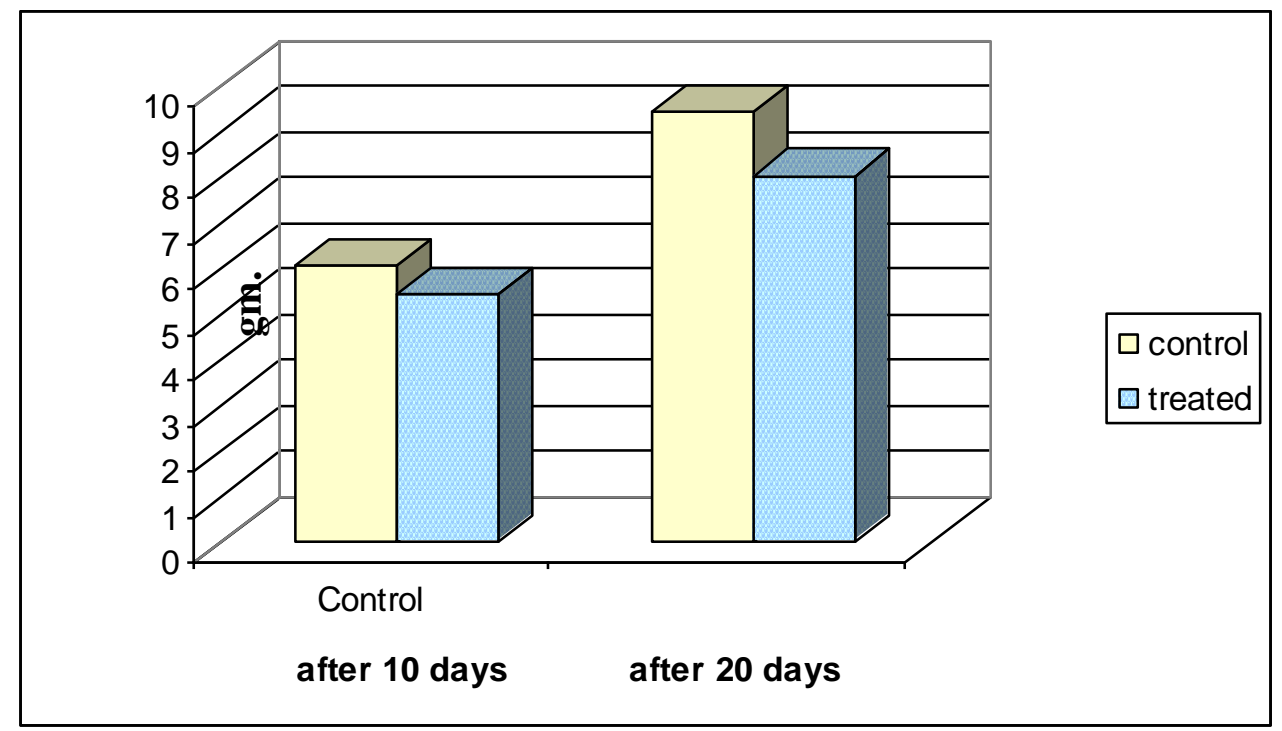

Fig .(1): changes in the body weight (gm) of control and Diazinon-treated rats.

Table(2): Effect of Diazinon insecticide on glucose level $(\mathrm{mg} / 100 \mathrm{ml})$, total cholesterol content $(\mathrm{mg} / \mathrm{dl})$ and total protein content $(\mathrm{gm} / \mathrm{dl})$ in albino rat serum

\begin{tabular}{|c|c|c|c|c|c|c|c|c|c|c|c|c|}
\hline & \multicolumn{4}{|c|}{ glucose } & \multicolumn{4}{|c|}{ Total cholesterol } & \multicolumn{4}{|c|}{ Total protein } \\
\hline & \multicolumn{2}{|c|}{10 days } & \multicolumn{2}{|c|}{20 days } & \multicolumn{2}{|c|}{20 days } & \multicolumn{2}{|c|}{20 days } & \multicolumn{2}{|c|}{10 days } & \multicolumn{2}{|c|}{20 days } \\
\hline & control & treated & control & treated & control & treated & control & treated & control & treated & control & treated \\
\hline $\begin{array}{l}\text { Mean } \\
\pm \text { S.D. }\end{array}$ & $\begin{array}{c}100.68 \\
\pm 2.25\end{array}$ & $\begin{array}{c}107.14 \\
\pm 1.86\end{array}$ & $\begin{array}{c}101.24 \\
\pm 1.98\end{array}$ & $\begin{array}{c}120.18 \\
\pm 2.21\end{array}$ & $\begin{array}{l}79.01 \\
\pm 0.37\end{array}$ & $\begin{array}{l}75.96 \\
\pm 1.02\end{array}$ & $\begin{array}{l}78.96 \\
\pm 0.47\end{array}$ & $\begin{array}{l}75.95 \\
\pm 3.45\end{array}$ & $\begin{array}{c}6.05 \\
\pm 0.02\end{array}$ & $\begin{array}{c}5.66 \\
\pm 0.48\end{array}$ & $\begin{array}{c}6.05 \\
\pm 0.03\end{array}$ & $\begin{array}{c}5.42 \\
\pm 0.49\end{array}$ \\
\hline $\begin{array}{c}\% \text { of } \\
\text { change }\end{array}$ & \multicolumn{2}{|c|}{+6.42} & \multicolumn{2}{|c|}{+18.71} & \multicolumn{2}{|c|}{-3.86} & \multicolumn{2}{|c|}{-3.81} & \multicolumn{2}{|c|}{-6.45} & \multicolumn{2}{|c|}{-10.41} \\
\hline$P$ value & \multicolumn{2}{|c|}{$\mathbf{P}<0.001 * * *$} & \multicolumn{2}{|c|}{$P<0.001 * * *$} & \multicolumn{2}{|c|}{$\mathbf{P}<0.001 * * *$} & \multicolumn{2}{|c|}{$\mathbf{P}<0.05^{* *}$} & \multicolumn{2}{|c|}{$\mathrm{P}<0.05^{* *}$} & \multicolumn{2}{|c|}{$\mathbf{P}<0.001 * * *$} \\
\hline
\end{tabular}

* Insignificant

*** Highly Significant 

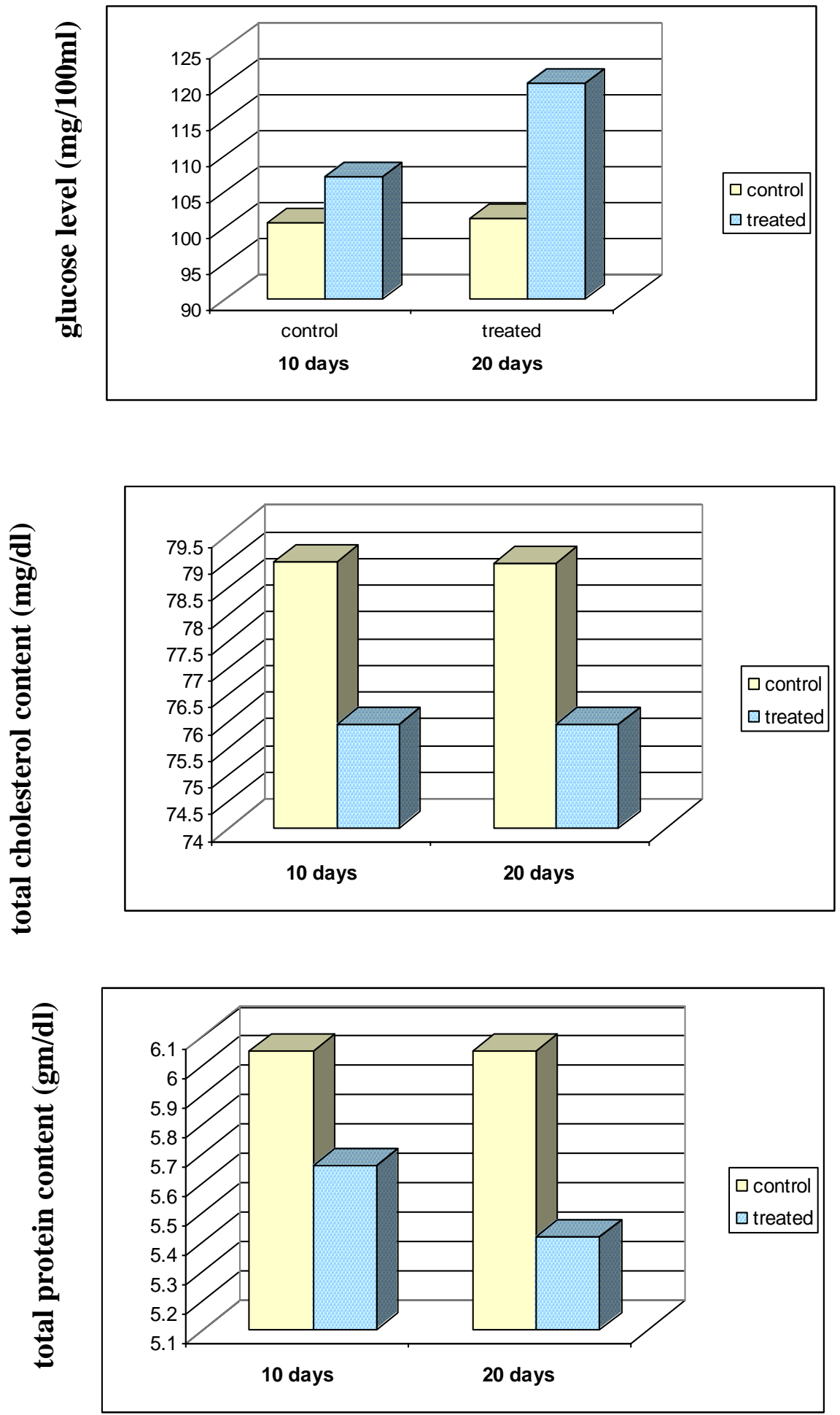

Fig (2):Effect of Diazinon insecticide on glucose level $(\mathrm{mg} / 100 \mathrm{ml})$, total cholesterol content $(\mathrm{mg} / \mathrm{dl})$ and total protein content $(\mathrm{g} / \mathrm{dl})$ in albino rat serum . 


\section{Mohammed Salah Ab.Ab.AL-Shinnawy}

Table(3): Effect of Diazinon insecticide on AST , ALT and ALP activities (U/ml) in male albino rat serum.

\begin{tabular}{|c|c|c|c|c|c|c|c|c|c|c|c|c|}
\hline & \multicolumn{4}{|c|}{ ASR } & \multicolumn{4}{|c|}{ ALT } & \multicolumn{4}{|c|}{ ALP } \\
\hline & \multicolumn{2}{|c|}{10 days } & \multicolumn{2}{|c|}{20 days } & \multicolumn{2}{|c|}{10 days } & \multicolumn{2}{|c|}{20 days } & \multicolumn{2}{|c|}{10 days } & \multicolumn{2}{|c|}{20 days } \\
\hline & control & treated & control & treated & control & treated & control & treated & control & treated & control & treated \\
\hline $\begin{array}{l}\text { Mean } \\
\pm \text { S.D. }\end{array}$ & $\begin{array}{c}138.75 \\
\pm 9.43\end{array}$ & $\begin{array}{c}133.50 \\
\pm 9.43\end{array}$ & $\begin{array}{c}137.18 \\
\pm 7.92\end{array}$ & $\begin{array}{c}207.75 \\
\pm 5.88\end{array}$ & $\begin{array}{l}85.13 \\
\pm 6.01\end{array}$ & $\begin{array}{l}82.50 \\
\pm 3.17\end{array}$ & $\begin{array}{l}86.03 \\
\pm 4.16\end{array}$ & $\begin{array}{c}11.83 \\
\pm 11.23\end{array}$ & $\begin{array}{r}187.83 \\
\pm 11.23\end{array}$ & $\begin{array}{l}180.52 \\
\pm 15.81\end{array}$ & $\begin{array}{c}180.74 \\
\pm 7.21\end{array}$ & $\begin{array}{c}185.16 \\
\pm 2.81\end{array}$ \\
\hline $\begin{array}{c}\% \text { of } \\
\text { change }\end{array}$ & \multicolumn{2}{|c|}{-3.78} & \multicolumn{2}{|c|}{+50.75} & \multicolumn{2}{|c|}{$3.09-$} & \multicolumn{2}{|c|}{+36.58} & \multicolumn{2}{|c|}{-3.89} & \multicolumn{2}{|c|}{+2.45} \\
\hline$P$ value & \multicolumn{2}{|c|}{$P<0.05 *$} & \multicolumn{2}{|c|}{$\mathbf{P}<0.001 * * *$} & \multicolumn{2}{|c|}{$\mathrm{P}<0.05^{*}$} & \multicolumn{2}{|c|}{$\mathbf{P}<0.001 * * *$} & \multicolumn{2}{|c|}{$\mathrm{P}<0.05^{*}$} & \multicolumn{2}{|c|}{$\mathrm{P}<0.05^{*}$} \\
\hline
\end{tabular}

* Insignificant
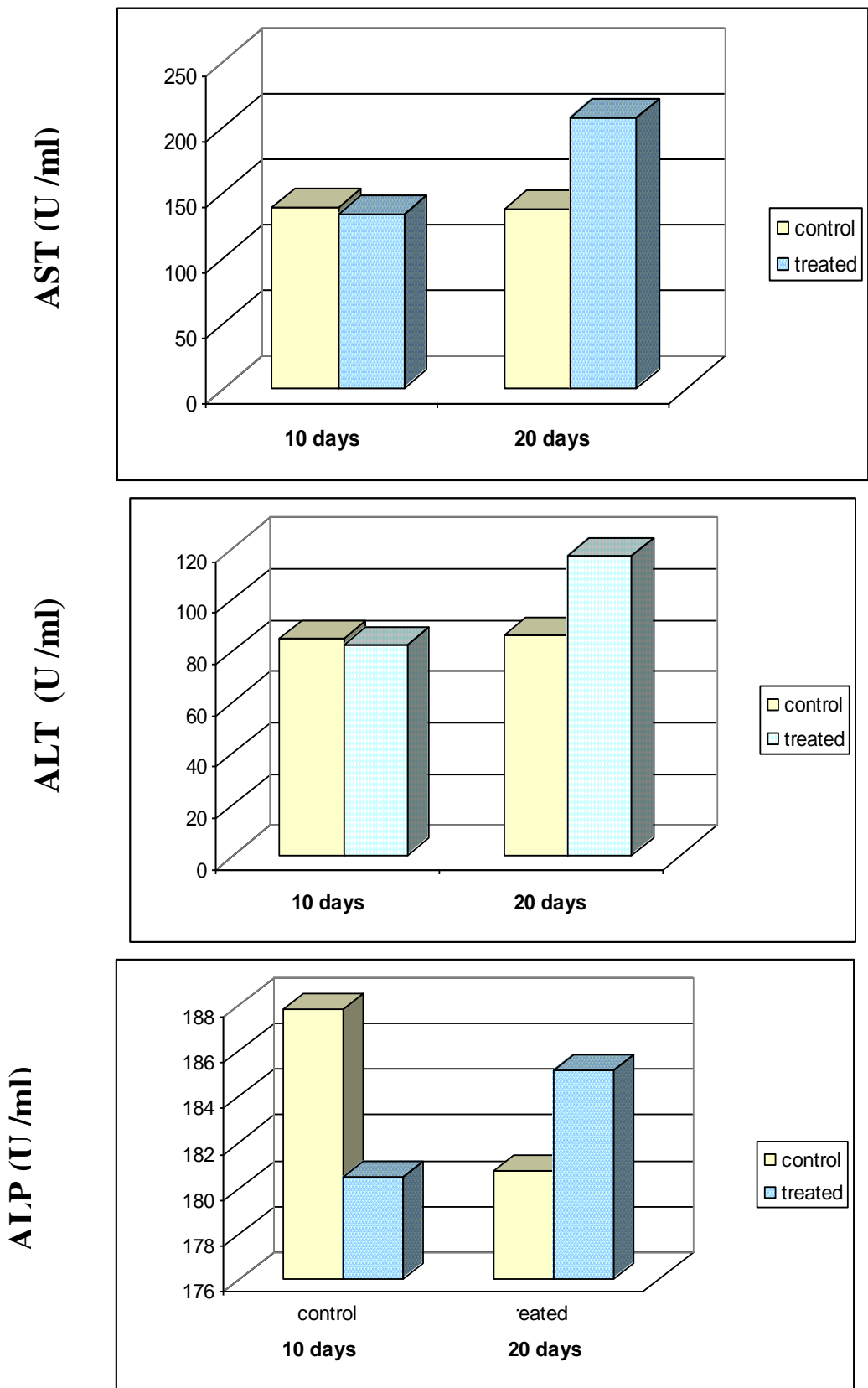

Fig (3) : Effect of Diazinon insecticide on AST , ALT and ALP activities (U / $\mathrm{ml}$ ) in albino rat serum 
Table(4): Effect of Diazinon insecticide on thyroxine (T4) $(\mu \mathrm{g} / \mathrm{dl})$ and tri - iodiothyronine (T3) $(\mathrm{ng} / \mathrm{ml})$ concentrations in albino rat serum.

\begin{tabular}{|c|c|c|c|c|c|c|c|c|}
\hline & \multicolumn{4}{|c|}{ Tri - iodiothyronine (T3) (ng/ml) } & \multicolumn{4}{|c|}{ Thyroxine (T4) ( $\mu \mathrm{g} / \mathrm{dl})$} \\
\hline & \multicolumn{2}{|c|}{10 days } & \multicolumn{2}{|c|}{20 days } & \multicolumn{2}{|c|}{10 days } & \multicolumn{2}{|c|}{20 days } \\
\hline & control & treated & control & treated & control & treated & control & treated \\
\hline $\begin{array}{l}\text { Mean of body } \\
\text { weight (gain or } \\
\text { loss gm .) } \\
\text { (Mean } \pm \text { S . D) }\end{array}$ & $\begin{array}{c}1.04 \\
\pm 0.09\end{array}$ & $\begin{array}{c}1.22 \\
\pm 0.06\end{array}$ & $\begin{array}{c}1.02 \\
\pm 0.08\end{array}$ & $\begin{array}{c}1.35 \\
\pm 0.19\end{array}$ & $\begin{array}{r}12.02 \\
\pm 1.89\end{array}$ & $\begin{array}{c}12.82 \\
\pm 1.58\end{array}$ & $\begin{array}{r}12.09 \\
\pm 1.74\end{array}$ & $\begin{array}{c}15.21 \\
\pm 1.88\end{array}$ \\
\hline$\%$ of change & \multicolumn{2}{|c|}{+17.31} & \multicolumn{2}{|c|}{+32.35} & \multicolumn{2}{|c|}{+6.66} & \multicolumn{2}{|c|}{+25.81} \\
\hline$P$ value & \multicolumn{2}{|c|}{$\mathbf{P}<0.001 * * *$} & \multicolumn{2}{|c|}{$\mathbf{P}<0.001 * * *$} & \multicolumn{2}{|c|}{$P<0.05^{*}$} & \multicolumn{2}{|c|}{$\mathrm{P}<0.05^{*}$} \\
\hline
\end{tabular}

* Insignificant $\quad$ ** Significant $\quad * * *$ Highly Significant
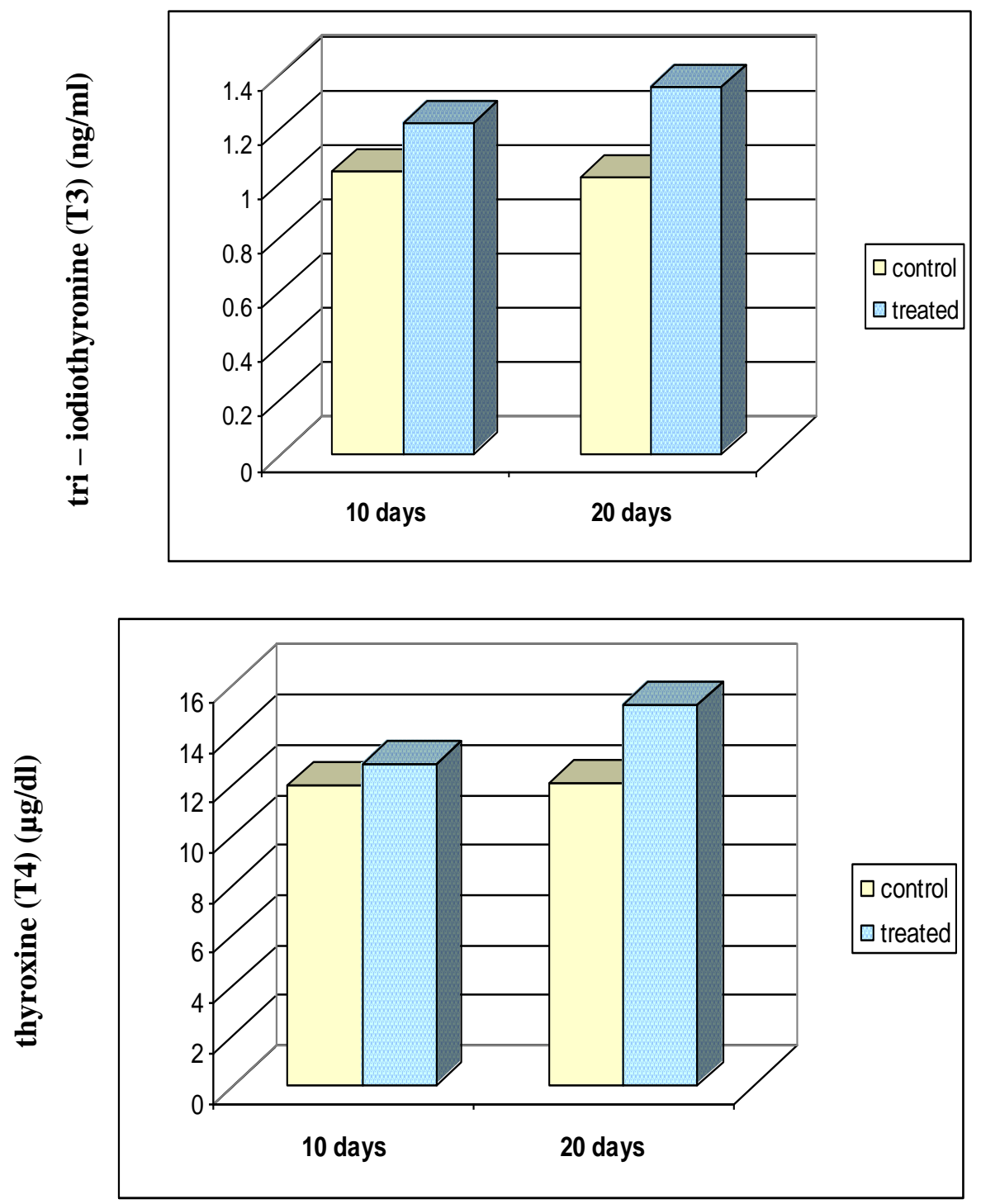

Fig (4) : Effect of Diazinon insecticide on thyroxine (T4) ( $\mu \mathrm{g} / \mathrm{dl})$ and tri - iodiothyronine (T3) $(\mathrm{ng} / \mathrm{ml})$ concentrations in albino rat serum 


\section{Discussion}

There is an increasing interest from the hygienic point of view for the safety of the feeding stuffs for consumption. The intensive use of pesticides to eliminate pests or to regulate crop growth has led to pesticide residues in soil, air, water, stored grains, crops and plants at concentration levels which exceed the legal limits(Süsse and Müller,1996). The great hazards caused by pesticides on the live stocks are due to their accidental exposure to these pesticides either by ingestion or inhalation (Yamanaka et al., 1996). The disappearance of pesticide residues at a given location does not mean the end of the problem, but they can be translocated, bioconcentrated or converted into more dangerous chemicals (Mastmura, 1985). Therefore, This study was designed to evaluate the influence of these compounds on adult male albino rats.

The results of the present investigation revealed that only those rats fed on diazinon showed highly significant decreases in their body weights after feeding for 20 days. This decrease may probably attribute to the loss of appetite, lesser food intake and/or metabolic disturbance caused by diazinon treatment. These results are in harmony with those obtained by (Dikdshith et al., 1991) on hexachlorocyclic hexane, (Badawy et al.,1992) on curacron, (Paul et al.,1993) on Endosulfan (Abd ElHady and Abdeen ,1997).Also, the loss of body weight may be due to diarrhea, diabetes and decreased nucleic acid contents (Rashwan et al ., 1994).

There exists a positive correlation between relative body weight and concentrations of lipids(Harper et al.,1993).

In the present investigation high level of serum glucose were recorded in all groups of diazinon treated rats. These results are in good agreement with those findings obtained by Areechon and Plumb (1990) ; Thaker and Garg (1993); kumar et al. (1996); Gad (2000) and Fouda(2004) .

The hyperglycemia observed in the present work may be due to diazinon administration enhance the activities of the enzymes involved in gluconeogenesis leading to formation of glucose from noncarbohydrate source(Evans,1996).
The weight loss encountered in this study may be a consequence to diazinon which appears to have a hypocholesterolemic effect as revealed by a decrease in total serum cholesterol content of the corresponding rat groups. These results are supported by the findings of Shakoori et al . (1988) and Saleh (1990).

Serum total protein in this study exhibited a significant decrease in rats fed on diazinon after 10 days, while total protein revealed a highly significant decrease after 20 days(table2). This result is in accordance to those of Saleh et al. (1993);Sova et al. (1992) and Mossad \&Azab(1999). This decrease in serum total protein level may be due to several pathological processes including renal damage and elimination of protein in the urine as explained by Pfeifer and Weber (1979). Regarding the effect of some insecticides on blood proteins, the result reported by several authors are contradictory. This contradiction may be attributed to several factors such as the type and used dose sex of the experimental animals ,organ under investigation and period of treatment.

The obtained data (recorded in table 3), short-term administration of diazinon showed insignificant changes in the activity of AST,ALT and ALP in rats. The activity of transaminases(AST,ALT)after long-term administration of diazinon, was highly significant increased .Elevations of transaminase activity in blood have been considered as indicator of tissue damage.

Similar results were reported by Abdel Mageed et al.(2001); Fouda \& Azab (2003), and El-Shater(2003).The authors indicated that insecticides caused an increase in serum AST and ALT activities in several species of animals.

The results obtained for T3(triiodothyronine)levels revealed a high significant increase in all groups of diazinon treated rats.Concerning $\mathrm{T} 4$ (thyroxine) level in serum of rats, it was found that administration of diazinon for 20 days only led to a significant increase in $\mathrm{T} 4$ concentration.

The literatures concerning the effect of insecticides on thyroid function are 
rather contradictory and conflicting results of the present investigation seems to be in agreement with Rusmey et al.(1983) and Yadav \& Singh (1987) who stated that organophosphorus had a stimulating effect on thyroid function in beef steers. Many authors reported significant decrease in T3and T4 after treatment with organophosphorus insecticides on rats[ Akhtar et al. (1996) ; Hasheesh et al.(2002)and ElShater (2003)].

Generally the increase in activity of T3 and T4 of thyroid gland paralleled the reduction of total cholesterol in serum and the degradation process of body weight in rats fed on diazinon. Hyperthyroidism may play a significant role in the genesis of decreasing serum lipids content of rats fed on organophosphorus insecticides. Therefore ,the reduction of body weight may be attributed to the stimulation of thyroid gland.

\section{Concolusion}

Because all the harmful alterations that diazinon had caused,the present investigation recommended for taking the almost care and minimize the use of this pesticide.

\section{References}

1. Abdel-Hady E K and Abdeen AM(1997): Biochemical and histopathological observations on the influence of dimethoate and nuvacron insecticides on pregnant rats and their newborn .J. Union Arab Biol . 7(A): 75-107.

2. Abdel-Mageed FA, Nessiem AL and Nour EL-Dien SM (2001): Biochemical studies on the interactions of certain xenobiotics with metronidazole in rats .J. Egypt. Ger. Soc. Zool., 34(A) : 245-254.

3. Akhtar N, Kayani S A, Ahmed M M and Shahab M (1996): Insecticide induced changes in secretory activity of the thyroid gland in rats. J. App. Toxicol., 16(5): 397400 .

4. Allain CC, Poon LS, Chan CSG, Richmond $W$ and Fu P C (1974): Enzymatic determination of total serum cholesterol . Clin. Chem., 20:470.

5. Alpalan G, Kanat Hilmi D, Dilek B and Altuntas I (2006): Effects of diazinon at different doses on rat liver and pancreas tissues. Depart. of Biochem.Suleyman Demirel Univ. Sch. of Med. Isparta. Turk. Pest. Biochem.and Phyiol .,87 (2):103-108.

6. Areechon N and Plumb J A (1990):
Sublethal effects of malathion on channel catfish Ictalurus punctatus .Bull. of environ. Contam.Toxicol., 44(3): 435-442 .

7. Badawy M E; Amer TA ;Ibrahim H A and El-Sawi M R (1992): Curacron toxicity in relation to some physical and biochemical parameters in rat. J. Egypt. Ger. Soc. Zool., 8(A):101-119.

8. Belfield A and Golbderg DM (1971): Colorimetric determination of alkaline phosphatase (ALP) activity Enzymes In : J.Clin. Chem. Clin.Biochem.,8: 561

9. Berg Meyer H V and Bernt E (1974): Spectrophotometric determination of amino acid transaminases In: Bergmeyerand, $\mathrm{H} \mathrm{U}$ and Bernt E. (Eds). Methods of enzymatic Analysis Academic Press, Orlando F L pp.320-401.

10. Cindy $S \mathbf{R}$; Olga A T ; Frederic J S ; Theodore A S and Edward, D L (2007): Development Diazinon neurotoxicity in rats. [Depart. of Psychiatry and Behavioral Sciences, Duke University Medical Center, Durham ,NC27710, USA].Brain Research Bull. 5(1):166-172.

11. Compbell R C (1974): Statistics for Biologists.2nd ed. Cambridge Univ .press, Cambridge, England.

12. Diskshith T S S, Raizada R B and Srivastava M K (1991): Long -term dietary study and development of no observed effect level of technical $\mathrm{HCH}$ to rats .J.Toxicol . Environ. Health., 34(1): 495-507.

13. Domas B T (1975): Standards for total serum protein assays. A collaborative study .Clinical Chemistry,21:1159-1166 .

14. El-Shater A A (2003): Effects of the organophosphorus Insecticide parathion on the secretory activity of the thyroid gland and on some biochemical and haematological parameters of adult male rats .J. Egypt .Ger . Soc .Zool ., 40(A):447-456.

15. Evans OG (1996): Animal clinical chemistry.A primer for toxicologists 1st Ed.,pp. 73-98.

16. Ezzat A R; Saleh F; El-Saify A A and ElShater A A (1991): Thyroid function and lipid metabolism in pigeon treated with insecticides acetellic and cypermethrin . J. Egypt . Ger . Soc .Zool ., (3):75-84 .

17. Fouda F $M$ and Azab A M (2003): A comparative toxicological study on the effects of chemical and biological pesticides on the liver of Nile catfish, Clarias gariepinus.J. Egypt. Ger. Soc. Zool .,40(A):105-120.

18. Fouda F M (2004):Haematological and biochemical studies on the effects of a biological and chemical pesticides on the Nile Catfish,Clarias gariepinus.J.Egypt. Ger .Soc.Zool.,43(A):77-97. 
19. Gad O E A (2000): Toxicological studies on some pesticides with special reference to its cytogenetic effect. $\mathrm{Ph}$.D. Thesis, Department of Forensic Medicine and Toxicology, Faculty of Veterinary Medicine, Suez Canal University.

20. Gralewicz $S$ and Socko $R$ (1997): Persisting behavioral and electroencephalographic effects of exposure to chlorphenvinphos, an organophosphorus pesticide, in Laboratory animals . Int . J . Occup . Med . Environ . Health , 10(4) : 375-394.

21. Harper H A; Rodwell V W and Mayes $P$ A (1993): Review of physiological chemistry ,Middle East Edition,Lange Medical Publications,P.511-537.

22. Hasheesh W S ; Assem M M S ;Fakhry F $M$ and Mohamed E A A (2002): Effect of the organophosphorus pesticide triazophos on the thyroidal and gonadal hormones in male albino rats.J.Egypt .Ger. Soc. Zod., 37 (A): 425-442.

23. Hassal K A (1990): The biochemistry and uses of pesticides : Structure, metabolism, mode of action and uses in crop protection . Macmillan press Ltd, Hong Kong, PP.1-81

24. Kalender S ;Ogutcu, A ; Uzunhisarcikli M ; Durak D and Ulusoy Y (2005):Effect of diazinon on Serum calcium and inorganic phosphate levels as well as ultrastructure .J. Environ Biol.211:197-206

25. Kumar H ;Gupta A B and Srivastave A K (1996): Physiological responses of a freshwater telecast Heteropneustes fossilis (Bloch) to an organophosphorus insecticide (metasystox).Flora and Fauna J.,2(1):65-67.

26. Mastmura F (1985): Toxicology of insecticides -2 nd Ed,Plenium Press Newyork, PP.267-270.

27. Mosaad M N M and Azab A E (1999) : Blood morphology and serum proteins in pigeon after the administration of propoxur .J.Egypt .Ger .Soc .Zool. , 30(A): 153-161.

28. Paul V, Sheela S, Balsubramaniam E and Zaki M (1993):Behavioral and biochemical changes produced by repeated oral administration of insecticide endosulfan in immature rats. Indian J. Physiol. Pharmacol. ,37(3):204-208.

29. Pfeifer K F and Weber L J (1979): The effect of carbon tetrachloride on the total plasma protein concentration of rainbow trout,Salmo gairdneri ,Comp. Biochem. Physiol., 64(c):37-42.

30. Rashwan S, Khalil H, Abd El-Kader H ;Abd El-Raouf S and Zaghloul S (1994): Histological ,ultrastructurcural and histochemical study on the effect of dexamethasone on the liver of rat. Sci. Conf. Egypt. Soc.Hist .Cyt. ,Fac. Med., Cairo Univ.
31. Rusmey $\mathbf{T} \mathbf{S}$, Bitman $\mathbf{J}$ and Tao $\mathbf{H}$ (1983):Changes in plasma concentrations of thyroxine, triiodo thyronine,cholesterol and total lipid in beef steers fed Rounel.J.Anim.Sci.,56(1):125-131 .

32. Saleh A M (1993): Ascorbic acid on dimethoate induced Kidney injury in albino rats.Menoufia Med .J.,5:69-81.

33. Saleh F (1990): Metabolic effects of carbamate insecticide (methomyl) on rats.III:Changes in some blood biochemical indices in the rats poisoned with the insecticide. Egypt J. Physiol. Sci., 14(12):65-74.

34. Saleh F (1990): Effect of synthetic pyrethroid cypermethrin on lipid metabolism in pigeons . J . Egypt .Ger.Soc.Zool.,1:67-77.

35. Shakoori A R;Ali S S and Saleem M A (1988): Effect of Six months feeding of cypermethrin on the blood and liver of albino rats . J. Biochem . Toxicol., 3:59-72.

36. Sova Z; Reisnerova N;Taborsky J; Slamova A;Vodickova H; Pohunkova H and Haisl K(1992): Effects of atrazine on the haematological and metabolic values ,formation of residues , and histological findings in laying hens. Biopharm., 2(1-2): 53-61 .

37. Süsse, $H$ and Müller, H (1996): Pesticide analysis by micellar electrokinetic capillary chromatography . J.chromatography, A., 730:337-343.

38. Sungur $M$ and Güven $\mathbf{M ( 2 0 0 1 )}$ :Intensive care management of orangophosphate insecticide poisoning . Crit . Care, 5:211-215.

39. Thaker A M and Garg B D (1993): Biochemical alterations in chicks following long term exposure to endosulfan and malathion. Indian J . of Poultry - Sci ., 28(1):51-55.

40. Trinder P (1969): Determination of glucose in blood glucose oxidase with an alternative oxygen acceptor . Ann . Clin . Biochem ., 6:24-27 .

41. Wood W G (1980):A second external guality control surver (EQCS) for serum triiodothyronine (T3) and thyroxine (T4)assays using the Munich model .J. Clin. Chem. and Clin.Biochem.,18-511.

42. Yadav A $K$ and Singh $T P$ (1987): Pesticide induced changes in peripheral thyroid hormone levels during different reproductive phases in Heteropneusters fossilis - Ecotoxicol. Environ. Saf ., 13 (1): 97-103.

43. Yamanaka S, Ohta K I, Tomito Y T okayanagi A, Nomara $T$ and Takaesu $Y$ (1996): Effect of acute organophosphorus poisoning in rats a gain and solubility of organophasphates. Environ . Health Prev. Med., 1(3):119-127. 
تأثيرات الايازينون على بعض المقاييس الكيموحيوية فى ذكور الجرذان

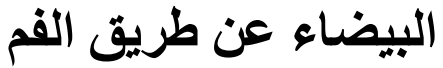

\section{محمد صلاح عبد الحمبا عبد الله الشناوى}

قسم العلوم البيولوجية ـ كلية التربية ـ جامعة عين شمس عدي مصر ـ القاهرة

فى هذه الدر اسة عوملت ذكور الجرذان البيضاء البالغة بجر عة يو ئنة مية من المبيد

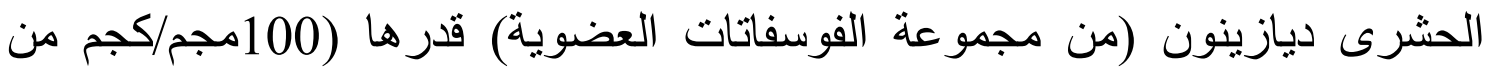

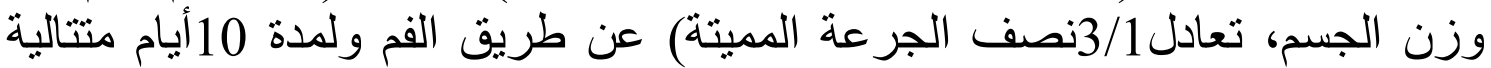
كمجمو عة أولى قصيرة الأمد ولمدة 20يو ما كمجمو عة أخرى طويلة الأمد) وأظهرت

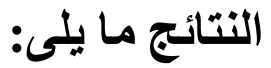

1- انخفض وزن جالف جسم الحيوانات المعاملة بالمبيد فى الفترة طويلة الأمد انخفاضا ملحوظا. 2- أدى إعطاء الديازينون إلى زيادة فى مستوى مصل دم الفئر ان من الجلوكوز وثلاثى الفي

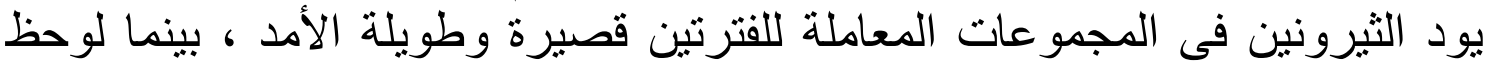

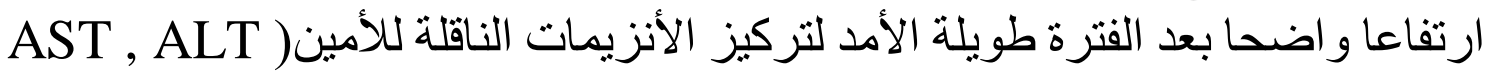
) إضافة إلى الثيروكسين.

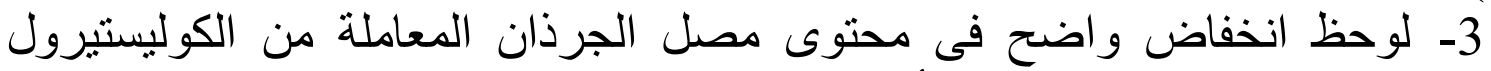
و البروتين الكلى للفترة قصيرة الأمد. 3- أظهر التحليل الإحصائى عدم تغير في تركيز التئ الأنزيمات الناقلة للأمين( , ALT

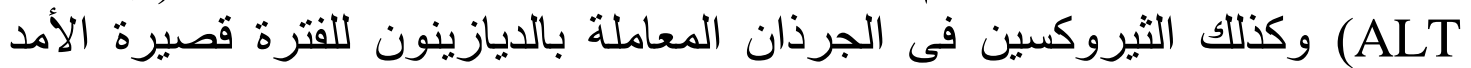

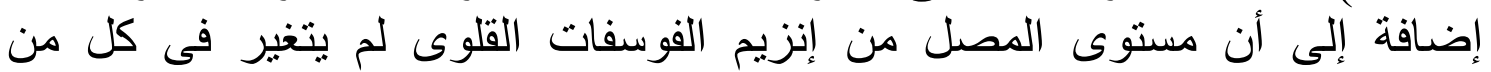
مجمو عتى الجرذان المعاملة خلال الفترتين قصيرة الفئ وطويلة الأمد . 